\title{
17. THE HYDROGEOLOGICAL REGIME OF ISOLATED SEDIMENT PONDS IN MID-OCEANIC RIDGES 1
}

\author{
Marcus G. Langseth, Lamont-Doherty Geological Observatory \\ Roy D. Hyndman, Pacific Geoscience Centre, Earth Physics Branch, Department of Energy, \\ Mines and Resources, Sidney, B. C. Canada \\ Keir Becker, Deep Sea Drilling Project, Scripps Institution of Oceanography \\ Stephen H. Hickman, United States Geological Survey, Menlo Park, California \\ and \\ Matthew H. Salisbury, Deep Sea Drilling Project, Scripps Institution of Oceanography²
}

\begin{abstract}
Temperature logs run on Leg 78B to a sub-bottom depth of $609 \mathrm{~m}$ in Hole 395A, Mid-Atlantic Ridge, indicate the presence of $2.5^{\circ} \mathrm{C}$ bottom water to a depth of about $300 \mathrm{~m}$ sub-bottom. Below this, the temperature rises slowly to $15^{\circ} \mathrm{C}$ near the bottom of the hole and then abruptly to $22^{\circ} \mathrm{C}$ in a thin layer of presumed sediment fill at the base. This temperature structure, together with the measurement of a subhydrostatic shut-in pressure of 0.9 to 1.5 bars at a sub-bottom depth of $179 \mathrm{~m}$, suggests that water is still flowing down the hole and into the basement five years after the hole was drilled. $\delta \mathrm{O}^{18}$ values in calcite taken from veins in the basement demonstrate that a similar temperature structure existed before drilling. Resistivity logs run in the same hole indicate that the upper $400 \mathrm{~m}$ of the crust is characterized by high porosity, but that the porosity drops markedly in the lower part of the section. This is consistent with direct measurements of permeability, obtained with a packer at a depth of $582 \mathrm{~m}$ sub-bottom, which range between 2.7 and $9 \mu$ darcies. These constraints, together with measured heat flow values of $40 \mathrm{~mW} / \mathrm{m}^{2}(20 \%$ of the expected theoretical value $)$ in the overlying sediment pond, suggest that the upper 400 to $500 \mathrm{~m}$ of crust around Hole $395 \mathrm{~A}$ is being cooled by the lateral flow of pore water moving at a rate of about $1 \mathrm{~m} / \mathrm{yr}$.
\end{abstract}

\section{INTRODUCTION}

The first indications that significant amounts of heat escaping from young lithosphere are being carried directly into the ocean bottom water by hydrothermal circulation of seawater within the basement came from seafloor heat-flow measurements (Lister, 1972; Talwani et al., 1971). On many mid-oceanic ridges deposition rates are low, and much of the sediment accumulates in flat-surfaced sediment ponds in topographic depressions. These ponds are typically 1 to $10 \mathrm{~km}$ across and 100 to $500 \mathrm{~m}$ thick. Most of the sediment is contributed to these ponds by turbidity-type flows from surrounding slopes (van Andel and Komar, 1969), although the processes that form the ponds are still poorly understood. Many ridge heat-flow measurements have been made in such ponds because they are among the few places where the thermal-gradient probes can be successfully inserted.

The heat-flow measurements show that the heat escaping through the upper surface of sediment ponds is only 10 to $30 \%$ of the predicted heat flow. Where a number of measurements were made in a single pond, they often yielded uniform values, although higher values are sometimes observed close to the rims of the

\footnotetext{
${ }^{1}$ Hyndman, R. D., Salisbury, M. H., et al., Init. Repts. DSDP, Vol. 78B: Washington (U.S. Govt. Printing Office).

2 Addresses: (Langseth) Lamont-Doherty Geological Observatory, Palisades, NY 10964 (Hyndman) Pacific Geoscience Centre, Earth Physics Branch, Dept. of Energy, Mines and Resources, Sidney, B.C. V8L 4B2 Canada; (Becker and Salisbury) Deep Sea Drilling Project, Scripps Institution of Oceanography, La Jolla, CA, 92093; (Hickman, present address) Dept. of Earth Sciences, Massachusetts Institute of Technology, Cambridge, MA 02139.
}

ponds. It is widely believed that the anomalously low heat flows result from extraction of geothermal heat from below the sediment pond by circulating seawater.

The simplest way to explain the observed result is to postulate that low-temperature pore water passing through a permeable ocean crust below the pond absorbs most of the geothermal heat. The heat is carried to the surrounding exposed rock surfaces, where it is lost to the bottom ocean water. We have few clues, however, as to the actual pattern or rate of flow or how these factors are controlled by the size of the sediment pond, age of the lithosphere, or permeability of the basement rock.

The first chance to look at the thermal regime at depth within and below a sediment pond was on Deep Sea Drilling Leg 37 (Hyndman et al., 1976) made when measurements were in holes drilled into basement, using a downhole temperature probe designed by R. P. Von Herzen (Erickson et al., 1975). Borehole temperature measurements were made in three different isolated sediment ponds that lie over crust of different ages. The important results from these measurements were as follows:

1) All three ponds yield heat flows significantly below those theoretically expected. Values range from $10 \%$ of theoretical at the youngest sites (3.5 Ma old) to $26 \%$ of theoretical for a pond on 8.9-Ma-old crust.

2) The anomalously low thermal gradients in the ponds result from low basement temperatures below the pond, demonstrating that depressed gradients measured by seafloor probes are not a surficial effect.

3) Temperature measurements in Hole 335 , in a sediment pond on 16.5-Ma-old crust, gave evidence for draw- 
down of water into the hole after it was drilled. This evidence for subhydrostatic pressure in basement rocks below a sediment pond was again observed on Leg 46 in Hole 396A, drilled through a small pond east of the Mid-Atlantic Ridge axis at $22^{\circ} \mathrm{N}$ (Erickson and Hyndman, 1979), and at several other DSDP sites.

Hyndman et al. (1976) interpreted these results as an indication of water circulation below the sediment pond, in the manner described above. Two results in the youngest pond suggested that the circulation penetrated deep into the crust. First, the four measurements of seafloor heat flow distributed across the pond have uniform values; and second, a nearly constant heat flow was observed to the bottom of one hole that penetrated more than $500 \mathrm{~m}$ into basement. The depth of seawater circulation in the crust as well as the depth to which it has a significant thermal effect remain important questions in marine hydrogeology.

\section{Leg 78B}

The return to Hole 395A on DSDP Leg 78B presented an excellent opportunity to examine comprehensively the hydrogeology of an isolated sediment pond. The hole was drilled in 1975 (on Leg 45) in an isolated pond (North Pond) lying on crust 7.2 Ma old, about $110 \mathrm{~km}$ west of the axis of the Mid-Atlantic Ridge. Hole 395A was drilled $1 \mathrm{~km}$ from the southeastern edge of North Pond, where the sediment is about $100 \mathrm{~m}$ thick. At its thickest point, the sediment in North Pond is about 300 $\mathrm{m}$ thick. The oldest sediment recovered from the hole near the sediment/basement interface is $6 \mathrm{Ma}$ old (Melson, Rabinowitz, et al., 1979). North Pond measures approximately $6 \mathrm{~km} \mathrm{E}-\mathrm{W}$ and $12 \mathrm{~km} \mathrm{~N}-\mathrm{S}$ (see Hussong et al., 1979 and Figs. 1A and 1B).

Hole 395A was drilled $571 \mathrm{~m}$ into basement. The basement lithology is mainly pillow basalts, but there are also three massive flow units and several thin layers described by the Leg 45 scientists as breccia (Melson, Rabinowitz, et al., 1979). The hole was undisturbed until the visit on Leg 78B five years later.

\section{SITE SURVEY RESULTS}

The geophysical survey conducted in North Pond by Hussong and co-workers before the Leg 45 drilling included sonobuoy seismic refraction measurements (Hussong et al., 1979; Kasahara et al., 1980). Their results indicate a layer having a compressional-wave velocity, $V_{p}$, of $4.6 \mathrm{~km} / \mathrm{s}$ in the upper $700 \mathrm{~m}$ of basement, overlying a $2.5-\mathrm{km}$-thick layer with an average velocity of 6.4 $\mathrm{km} / \mathrm{s}$. An interval velocity obtained with a borehole seismometer on Leg 78B, however, indicates that the average velocity in the upper $500 \mathrm{~m}$ of the basement at Site 395 is between 5.0 and $6.0 \mathrm{~km} / \mathrm{s}$ (Jacobsen et al., this volume). It has been demonstrated that the velocity of the upper kilometer of the basement is strongly controlled by its porosity (Whitmarsh, 1978; Kirkpatrick, 1979). Correlations between $V_{p}$ and porosity indicate a regional formation porosity of about 20 to $30 \%$ for the upper $700 \mathrm{~m}$ (see, e.g., Langseth and Herman, 1981) and a formation porosity of $10 \%$ in the upper $500 \mathrm{~m}$ of the crust immediately under the site (Hydman and Salis- bury, this volume). The survey refraction results indicate a relatively thin Layer 2 and Layer 3 .

Three successful heat-flow measurements in the southern part of North Pond, where the sediment is thickest, yielded values that average $39.5 \mathrm{~mW} / \mathrm{m}^{2}$ and agree to within 10\% (Fig. 1A; Hussong et al., 1979). The theoretically expected value over lithosphere 7.2 Ma old is about $180 \mathrm{~mW} / \mathrm{m}^{2}$, based on the "square root of age" relation of Davis and Lister (1977). Thus, only $20 \%$ of the heat escaping from the lithosphere reaches the upper surface of the sediment pond. The mean thermal gradient of $0.037^{\circ} \mathrm{C} / \mathrm{m}$, extrapolated to the top of the basement, predicts a temperature of about $10^{\circ} \mathrm{C}$. A fourth measurement made near the edge of the pond gave a relatively high value of $120 \mathrm{~mW} / \mathrm{m}^{2}$, which is still less than the theoretically expected value and most probably reflects the presence over basement of a thin sediment cover warmed by pore water flowing outward from under North Pond.

\section{DOWNHOLE MEASUREMENTS ON LEG 78B}

Nearly all of the downhole measurements on Leg 78B have relevance to the hydrogeology of North Pond and the underlying crust. All of these measurements and experiments are described in detail in other papers in this volume; temperature measurements are described by Becker et al; pressure and permeability experiments by Hickman, Langseth, and Svitek; wire-line logging measurements by Mathews et al.; and borehole televiewer results by Hickman, Svitek, and Langseth. The primary results of these measurements are reviewed here with emphasis on the temperature and permeability results.

\section{Temperature Observations}

The first measurements made after re-entering the hole on Leg 78B were temperature measurements in the borehole with the DSDP T-Probe (Yokota et al., 1980). Unfortunately, only one of the five attempts yielded reliable and accurate results. These temperatures are closely spaced observations between 371 and $400 \mathrm{~m}$ below the seafloor, and indicate temperatures between 5.66 and $7.34^{\circ} \mathrm{C}$ (see Fig. 2). These meager initial results indicated low gradients in the hole and the likelihood that the temperature gradient increased with depth in the hole.

Two wire-line temperature logs were made, one on 21 March at 1800 and the second $39 \mathrm{hrs}$. later on 23 March at $0900 \mathrm{hrs}$. The temperature logging tool has a small rapid-response thermistor that records temperature continuously. The observed temperature profiles are shown in Figure 2. There is a noticeable difference between the two temperature profiles, indicating that the hole was recovering from a thermal disturbance produced during re-entry. Disturbances in DSDP basement holes are difficult to avoid. The formation pressure is often subhydrostatic, so that water is drawn down into the hole; as a consequence, even at low pumping rates with the bit near the top of the hole, water at seafloor temperatures will flow deeper into the hole. The deeper extent of cooler water observed during the second logging run on 23 March between 250 and $350 \mathrm{~m}$ sub-bottom is proba- 


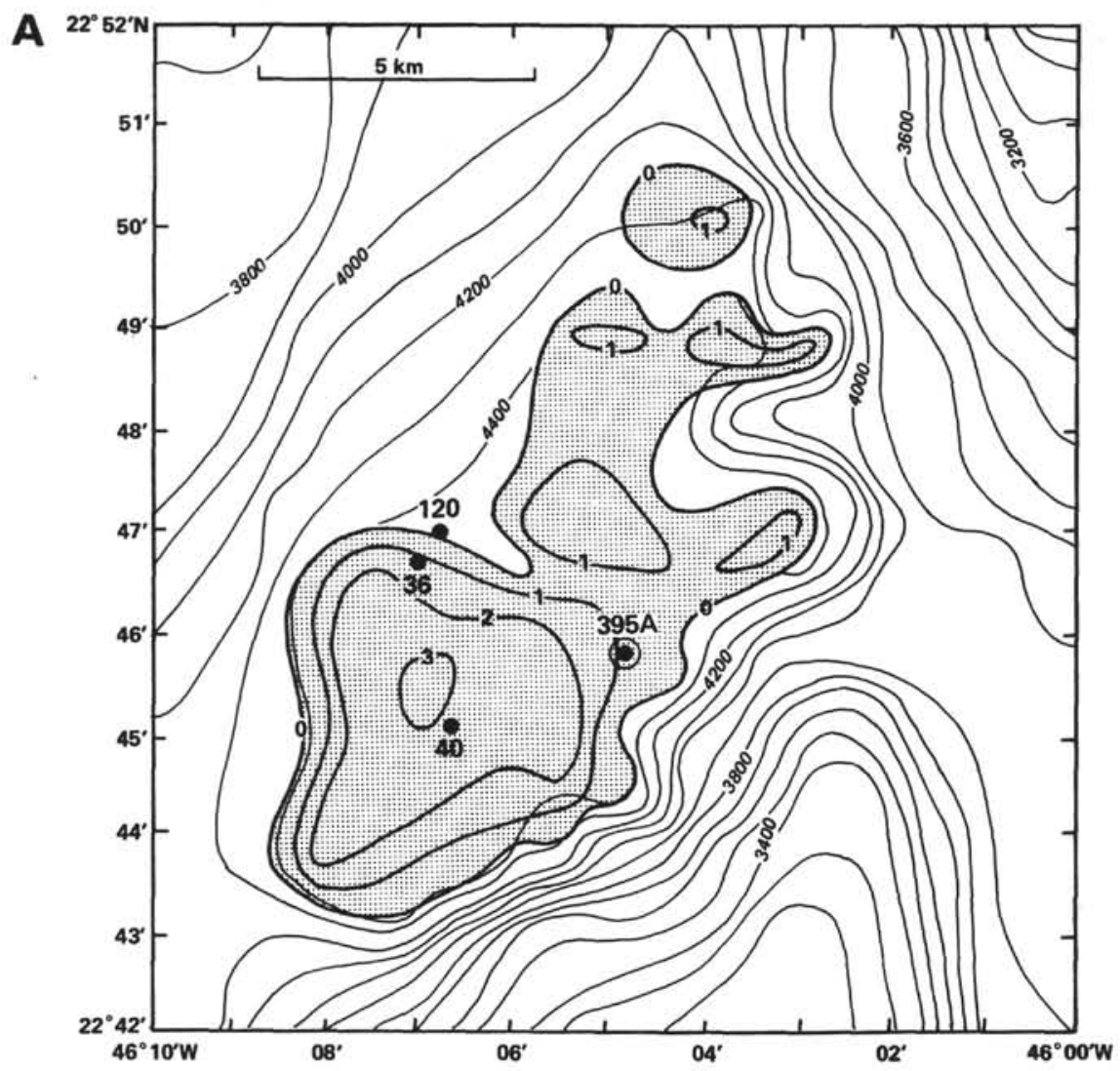

B 5.0 West

5.0 Tा

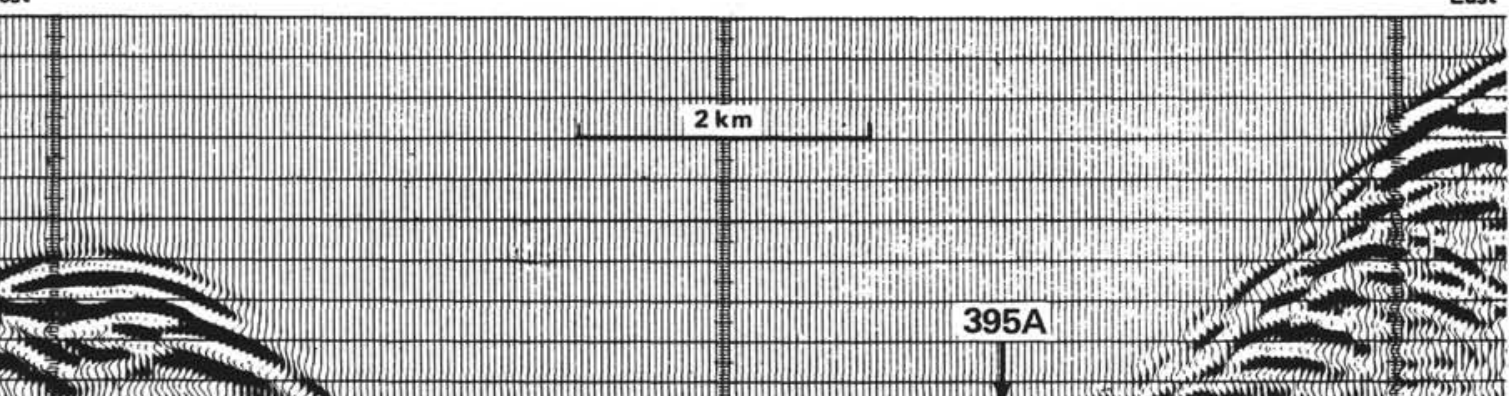

气 6.0 )

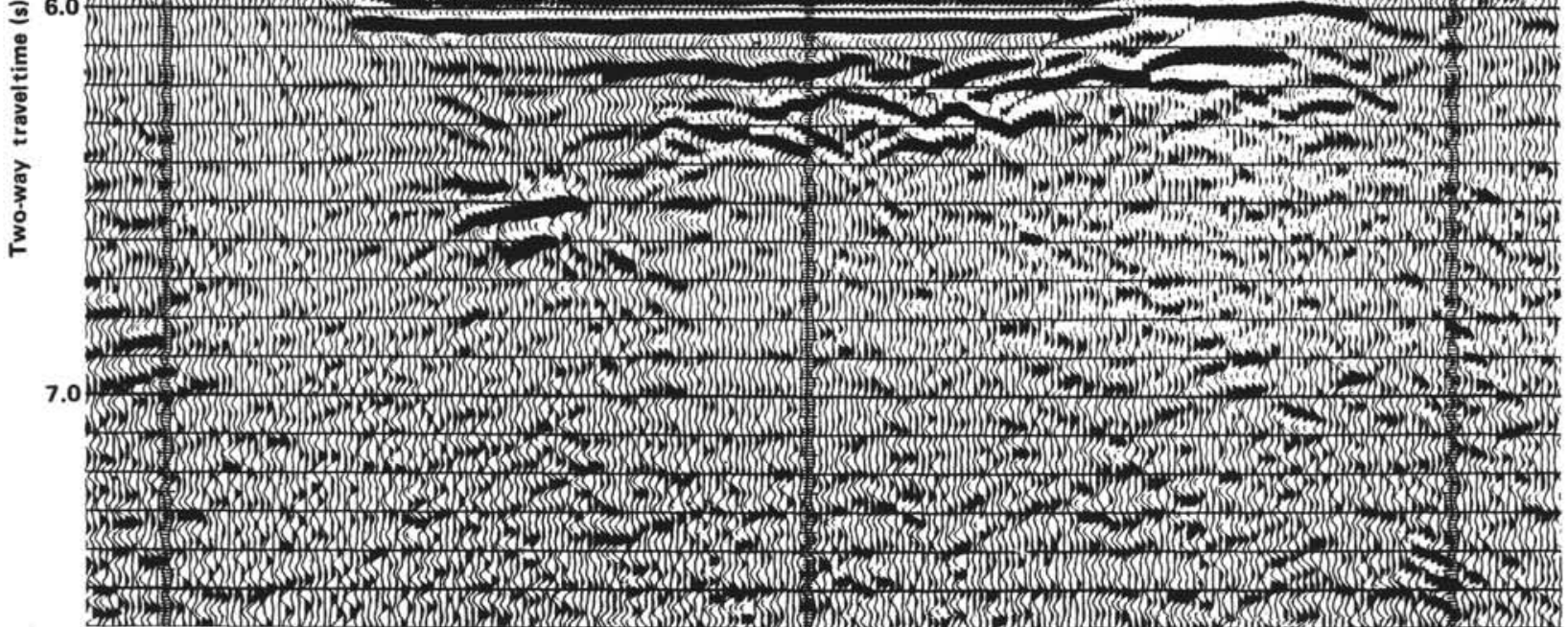

Figure 1. A. Extent (stippling) and thickness (isopachs in 0.1-s two-way travel time) of sediments in North Pond. Heat-flow measurement locations and values $\left(\mathrm{mW} / \mathrm{m}^{2}\right)$ from Hussong et al. (1979). Bathymetry in meters. B. Multichannel seismic reflection profile across North Pond. 

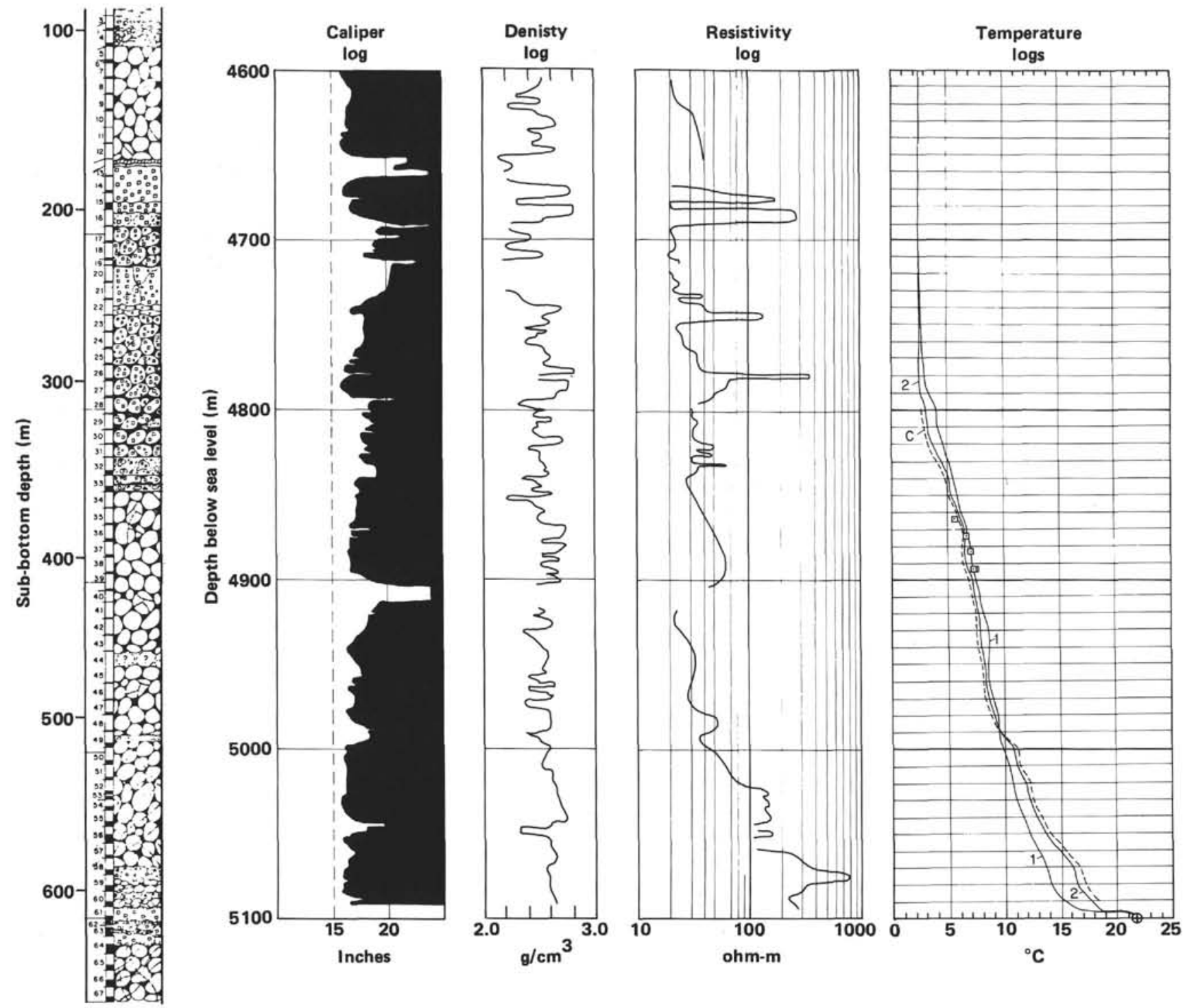

Packer and televiewer results depths in $\mathrm{m}$ below sea level) 4600

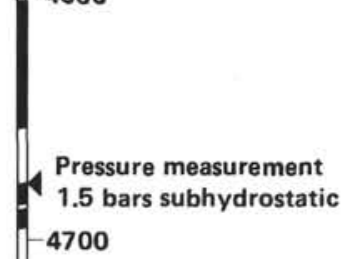

Figure 2. Six profiles of the basement in Hole 395A, based on cores, wire-line logging, and downhole experiments. The lithology profile on the left shows the recovery for each core (bars) and the nature of the recovered material (pillows, massive basalts and breccia-see Chapter 18, Fig. 1 [this volume] for key to lithologic symbols). The caliper, density, and resistivity logs have been smoothed by eye. The three temperature profiles shown are (1) the first high-resolution log run on 21 March; (2) the high-resolution log run on $23 \mathrm{March}, 39 \mathrm{hrs}$. later; and "C" (dashed curve), a profile which has been corrected for the thermal disturbance associated with re-entry (see Becker et al., this volume). The squares are T-probe measurements. In the profile on the right, the solid vertical bars indicate zones of high reflectivity defined by the borehole televiewer. 
bly a result of pumping combined with drawdown. Also, the borehole walls appear to have an exceptionally low permeability in the bottom $100 \mathrm{~m}$ of the hole (Hickman et al. this volume). Thus, pumping at the bottom of the hole to release the bit introduced cold water, which appears to have displaced the warmer water at the bottom of the hole about 100 to $150 \mathrm{~m}$ upward.

We have used the two temperature profiles to calculate the curve of equilibrium temperature versus depth, assuming that the disturbance in the lower $300 \mathrm{~m}$ was instantaneous. This calculation, described by Becker et al. (this volume), yields the dashed curve in Figure 2, which is our best estimate of the temperature profile in the bottom $200 \mathrm{~m}$ of the hole before re-entry on Leg 78B. The temperature curve of the 21 March logs (curve 1) provides the best estimate of temperatures before reentry for sub-bottom depths of less than $400 \mathrm{~m}$. these:

The notable features of the "equilibrium profile" are

1) To a sub-bottom depth of $250 \mathrm{~m}$, the temperature is constant at the bottom-water temperature value.

2) Between 250 and $500 \mathrm{~m}$ sub-bottom, the temperature increases slowly with depth to a value of about $10^{\circ} \mathrm{C}$. In the bottom $100 \mathrm{~m}$, the gradient increases to a value of about $0.085^{\circ} \mathrm{C} / \mathrm{m}$ and continues to increase with depth.

3) In the bottom few meters of the hole, the temperature jumps up abruptly to a value of $22^{\circ} \mathrm{C}$ from about $19^{\circ} \mathrm{C}$. The reason for this abrupt increase in not known with certainty. It occurs at a bridge in Hole 395A that prevented deeper penetration of the drill bit and logging tools on Leg 78B. One possibility is that a pocket of sediment or drilling mud may be sitting on top of the bridge and that the logging probe penetrated this sediment.

Two other temperature measurements of interest were provided by a thermometer in the DARPA boreholeseismometer package and by the DSDP T-Probe. The seismometer package sat at the bottom of the hole for $29.5 \mathrm{hrs}$. and recorded temperatures that extrapolate to an equilibrium value of $21.7^{\circ} \mathrm{C}$ (see Becker et al., this volume), thus substantiating the $22^{\circ} \mathrm{C}$ temperature measured by the logs.

The T-Probe measurement was taken $70 \mathrm{~m}$ deep in the sediment layer in Hole 395B, about $100 \mathrm{~m}$ northwest of Hole 395A. The T-Probe indicated low temperatures about $0.7^{\circ} \mathrm{C}$ above the bottom-water temperature. However, the 23-min. recording in the mud was jittery owing to continual movement of the drill bit in the mud. A considerable swell was running at the time this measurement was made. Because of this movement, the measurement $\left(3.25^{\circ} \mathrm{C}\right)$ only represents a lower limit of the in situ temperature.

An independent estimate of the basement temperature was made by Lawrence and Drever (1981) on the basis of the $\delta \mathrm{O}^{18}$ values of calcites in veins in basalts recovered from Hole 395A on Leg 45 (see Fig. 3). The temperatures they inferred for the upper $250 \mathrm{~m}$, using present seawater as a reference, are low, not significantly different from the bottom-water temperature. However, the temperatures one calculates from $\delta \mathrm{O}^{18}$ in calcite de-

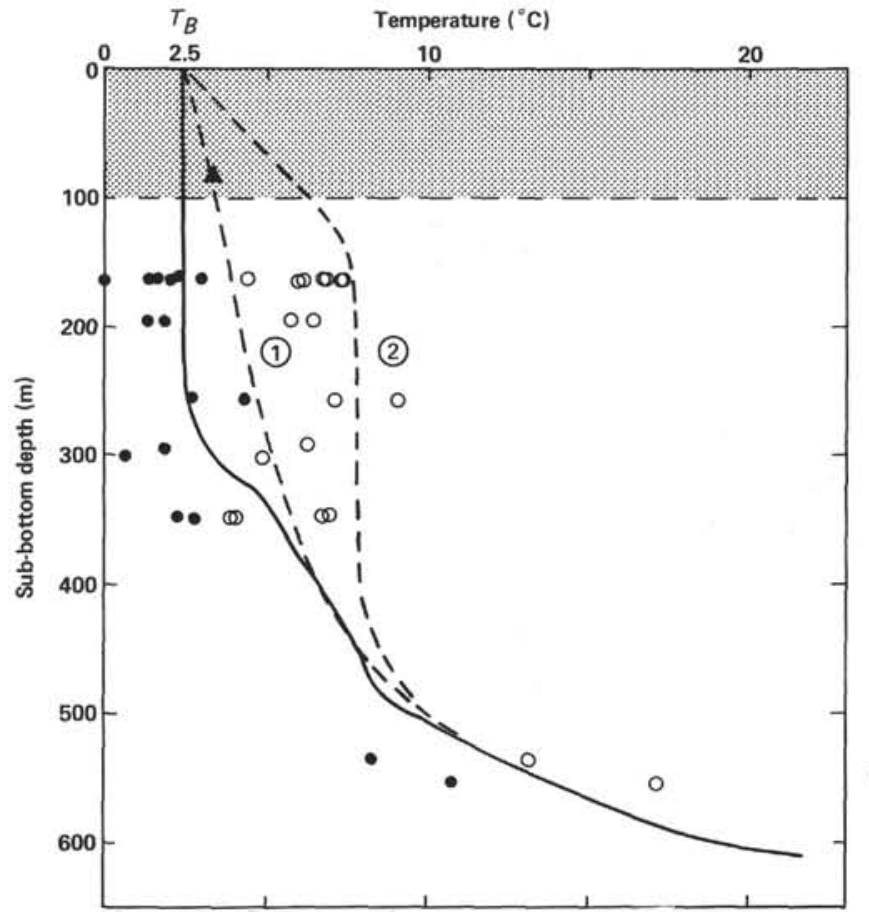

Figure 3. Three temperature profiles at Site 395, derived from the thermal data and simple models. The solid curve is our best estimate of the temperature profile in Hole 395A before re-entry. Curve 1 is an estimate of the pre-drilling temperature profile assuming nearly laminar horizontal flow in the upper $500 \mathrm{~m}$ of the basement. Curve $\mathbf{2}$ is an estimate of the pre-drilling profile assuming that the pore water in the upper $400 \mathrm{~m}$ is well mixed. $T_{B}$ is bottom-water temperature. Triangle represents T-probe measurement in Hole 395B. Dots and open circles correspond to temperatures determined from oxygen isotopic composition of calcite veins, assuming present-day isotopic composition of seawater (dots) and seawater composition associated with glacial maxima (circles). Stippled area represents sediment cover and white area is basalt basement.

pend on the Earth's ice volume at the time of calcite crystallization. If there was a low stand of sea level when the calcite precipitated, as inferred for the overlying sediments by McDuff (this volume), then temperatures about $5^{\circ} \mathrm{C}$ higher than for present-day stands of sea level are implied (see Fig. 3).

The importance of the $\delta \mathrm{O}^{18}$ measurements is that they indicate that low temperatures prevailed in the crust before drilling, and that these low temperatures have probably existed for much of the history of the crust below North Pond.

\section{Discussion of Temperature Measurements}

Isothermal temperatures to a depth greater than $250 \mathrm{~m}$ sub-bottom result from continual drawdown of bottom water into the hole. This water flows into permeable layers in the basement, but it is not known to what depth the downward flow extends. The increase in gradient below $300 \mathrm{~m}$ sub-bottom suggests a decrease in flow caused by the radial loss of water into the wall rock at higher levels, but some downward flux could continue to 400 or even $500 \mathrm{~m}$. Becker et al. (this volume) have estimated the rate of drawdown to be greater than 10 to 20 $\mathrm{m} / \mathrm{hr}$., assuming a pre-drilling gradient consistent with the seafloor heat flow of $40 \mathrm{~mW} / \mathrm{m}^{2}$. 
There is little doubt that the drawdown began when the hole was drilled, and that the flux of cold seawater down the hole has wiped out whatever gradients existed before drilling. An important question we address in this paper is what the pre-drilling temperature profile looked like. The measurement at $70 \mathrm{~m}$ in the sediment, taken at face value, predicts that the temperature at the top of the basement is $3.5^{\circ} \mathrm{C}$, and a more or less uniform increase would be expected to about $300 \mathrm{~m}$, where the temperature is about $5^{\circ} \mathrm{C}$ (see Fig. 3, curve 1). An alternative estimate assumes that the Hole 395B measurement is invalid and that the seafloor heat-flow measurements a few $\mathrm{km}$ to the west pertain. If these assumptions are correct, the temperature at the top of the basement is about $6.5^{\circ} \mathrm{C}$, and the pre-drilling temperature in the upper $300 \mathrm{~m}$ of oceanic basement would be essentially isothermal, indicating that the pore water is well mixed vertically throughout the layer (see Fig. 3, curve 2). Interestingly, the first hypothesis is in better agreement with $\delta \mathrm{O}^{18}$ temperatures calculated assuming present-day $\mathrm{O}^{18} / \mathrm{O}^{16}$ ratios in seawater, and the alternative hypothesis agrees with temperatures derived assuming ratios appropriate for glacial maxima.

\section{Downhole Permeability and Pore-Pressure Measurements}

An inflatable packer tool made by Lynes International was used to perform experiments downhole to estimate the permeability of the borehole wall rock, measure the "shut-in" pressure in the borehole, and collect large-volume water samples. A description of the packer and its operation is given by Hickman et al. (this volume).

Use of the Lynes packer tool on DSDP cruises to date has revealed a number of difficulties when it is employed in the oceanic basement. One of the primary problems is heave of the drilling ship that exceeds the throw of the telescoping joints (bumper-subs) in the bottom-hole assembly of the drill string. When these joints completely close or fully extend after the packer is inflated and set, the element is subjected to enormous axial impulsive forces which can destroy it. A second problem is that the walls of the hole are often extremely irregular, with large washouts and jagged projections (see the caliper $\log$ in Fig. 2). If the packer is inflated in a rough zone in the hole or in a washout, it is likely that the element will be destroyed.

During the first part of the cruise the sea conditions were good, and we were able to carry out permeability tests and take samples near the bottom of Hole 395A. The packer was also successfully inflated in a thick smooth-walled flow unit at $179 \mathrm{~m}$ sub-bottom (see Fig. 2), and an in situ pressure measurement was made. Subsequent to these tests taken on March 25, the swell slowly increased and our attempts to make further permeability tests ended unsuccessfully with the rubber element destroyed each time.

Permeability tests and a sampling operation were made at $582 \mathrm{~m}$ sub-bottom in a massive dolerite layer. The caliper and borehole televiewer logs show that the borehole in this interval has smooth walls with no obvious fractures or washouts. At $609 \mathrm{~m}$ sub-bottom the hole is obstructed, and the drill string could not be lowered any farther. There is uncertainty whether the rest of the hole drilled on Leg 45 , which continues to $664 \mathrm{~m}$, is hydraulically connected through the obstructed zone. The answer to this question is important in the interpretation of the permeability test and the hydrofracture attempt.

The permeability tests at $582 \mathrm{~m}$ sub-bottom indicated an extremely low bulk permeability. Two estimates were obtained: a value of $9 \times 10^{-18} \mathrm{~m}^{2}$ from a positive-pulse test, and a value of $2.7 \times 10^{-18} \mathrm{~m}^{2}$ from a large negative pulse created when the sampler was opened. The difference between these values may result from the opposite polarities of the pressure pulses. When a positive pressure is applied it will tend to open existing fractures in the surrounding rock, whereas a negative pulse will close them tighter. Permeability of this lower section of the hole was so low that pressure applied decreased only $20 \%$ during a one hour observation period.

The attempt to hydrofracture the formation with the packer set at $582 \mathrm{~m}$ sub-bottom was aborted at 152 bars above the hydrostatic pressure ( 55 bars above the lithostatic load) for fear of rupturing the packer element. The test did show that the borehole rock below $582 \mathrm{~m}$ has high tensile strength, and that the permeability of some rocks in the oceanic basement is low enough to permit a hydrofracture test. The high strength and extremely low permeability exhibited by the wall rock is puzzling. It would be most easily understood if the high pressure exerted during the test was confined to the dolerite sill and no open fractures intersected the drill hole; this would be true if the lower part of the hole was sealed by the obstruction at $609 \mathrm{~m}$ sub-bottom or if the hole had filled with impermeable sediments up to the obstruction. Alternatively, the lower part of the hole may indeed be impermeable. Two observations support this last hypothesis: (1) the heat flow approaches theoretical conductive values near the bottom of the hole, and (2) cores from the section of the hole below the obstruction, though highly fractured, are well cemented. Interestingly, these same cores showed a marked tendency to self-destruct in the core lab immediately after recovery on Leg 45 (Melson, Rabinowitz, et al., 1979). A desperate alternative hypothesis would be to invoke in situ stress as the cause of the high tensile strength and impermeability of the formation, and stress relief as the cause of the rock's behavior in the laboratory.

An additional uncertainty stems from the fact that an attempt was made on Leg 45 to cement the walls of the lower part of the hole. Hickman et al. (this volume) review the cementing operation and conclude that it is extremely unlikely that the 20 barrels of cement pumped into the hole at $636 \mathrm{~m}$ sub-bottom remained in the hole.

The pressure measurement at $179 \mathrm{~m}$ sub-bottom indicated a subhydrostatic pressure of between 0.9 and 1.5 bars ( $90-150 \mathrm{kPa})$, and during the observation period of about three hours a perceptible decrease in the pressure was recorded. An extrapolation of this trend backward in time provides a rough estimate of the in situ pressure when Hole 395A was drilled. Our analysis indicates about 3 bars. These measurements and estimates have 
large uncertainties, but give direct evidence of the subhydrostatic pressures required to drive the flow of water down the hole, inferred from the thermal data.

No direct test was obtained of the permeability of the section of the hole between 179 and $582 \mathrm{~m}$ sub-bottom. Later in this chapter we will estimate the permeability for this section of basement on the basis of simplified hydrological models.

In summary, then, the tests made using the packer showed that below $582 \mathrm{~m}$ sub-bottom the borehole has an extremely low permability (3-9 $\mu$ darcies), whereas the upper part of the crust appears to have a much higher permeability. Similar results have been reported for Hole 504B, Costa Rica Rift. We also achieved a direct in situ measurement of subhydrostatic pressure of at least 1.5 bars in an ocean crust hole.

\section{Borehole Televiewer}

The borehole televiewer is a downhole logging tool that makes an ultrasonic scan of the hole walls. The scan is made by a rotating transducer that transmits a pulse every $0.5 \mathrm{~ms}$ as the tool is slowly $(1.5 \mathrm{~m} / \mathrm{min}$.) drawn up the hole. The result is an image of the hole wall's reflectivity that is oriented with respect to north. The complete scan of Hole 395A is presented by Hickman et al. (this volume).

The tool did not perform as designed during the one run that was made on Leg 78B. The transducer rotated at only one third of the designed rate, which resulted in a reduction in line density by a Factor of 3 . In addition, heave of the drilling ship during the operation caused the tool to oscillate in the hole $3 \mathrm{~m}$ or more at periods of several seconds. This movement of the tool greatly degrades the vertical continuity of the image. Nevertheless, the images made by the borehole televiewer provide an informative picture of the walls of Hole 395A.

Where the hole wall is relatively smooth and the diameter is not much greater than the drill bit diameter, the televiewer image is uniformly light. In a few intervals, features such as cracks and outlines of basaltic pillows can be discerned. Massive flows, such as the ones at $179 \mathrm{~m}$ sub-bottom, and the dolerite units are clear on the record because the hole walls are smooth. On the other hand, intervals with large cavities and washouts reflect almost none of the sonic pulse and create a black zone on the film record.

The televiewer image of the hole wall indicates many areas of washout and high wall rugosity in the interval from 150 to $400 \mathrm{~m}$ sub-bottom. This implies that fragments of basement rock were dislodged from the hole wall during drilling, and that the surrounding rock is highly fractured and weakly cemented. This is consistent with other results that suggest that this interval has a high fracture porosity and relatively high permeability.

\section{Wire-Line Logging}

We briefly review the results from certain of the wireless logs that are pertinent to the hydrogeology of Hole 395A. We have of course made extensive reference already to the temperature logs, and we will not discuss them further here.
The two-arm caliper provided a valuable profile of the hole (see Fig. 2). The large washout zones between 165 and 180,210 and 230 , and 415 and $435 \mathrm{~m}$ sub-bottom correlate well with those shown by the borehole televiewer. The caliper log also helps to delimit massive flow units, since the hole is usually smooth and close to gauge through them. The flows between 180 and $210 \mathrm{~m}$ and the dolerite units from 585 to $600 \mathrm{~m}$ can be seen.

The profile of density in Figure 2 was obtained using a sled-type gamma-gamma backscattering tool. Reliable results can only be obtained with such a tool when the walls of the hole are smooth. The massive flow at $180 \mathrm{~m}$ shows up well, and the bottom $100 \mathrm{~m}$ of the hole is seen to have a relatively high corrected density that varies between 2.5 and $2.8 \mathrm{~g} / \mathrm{cm}^{3}$. Since a comparison of the resistivity and density data shows that the density tool gave systematically low values, however, the density data may only be used qualitatively (Mathews et al., this volume).

Resistivity was logged with a laterolog tool (see Fig. 2 and Mathews et al., this volume). The most notable feature of the resistivity profile is an order of magnitude increase in resistivity in the bottom $100 \mathrm{~m}$ of the hole. In the case of ocean crust, the increase in resistivity corresponds to a decrease in the number and size of connections between fractures and voids. Thus, the change observed here is consistent with the large decrease in hydraulic permeability indicated by the thermal data and the packer experiments.

\section{Summary of Downhole Measurement Results}

Taken together, the measurements and experiments in Hole 395A show a consistent picture of the thermal and hydraulic properties of the upper one-half $\mathrm{km}$ of the ocean crust below North Pond. The temperature of the upper $400 \mathrm{~m}$ of the basement is only 1 to $8^{\circ} \mathrm{C}$ above bottom-water temperature. The pore-water pressure in the basement section of Hole $395 \mathrm{~A}$ is subhydrostatic. In terms of its hydraulic properties, the ocean crust below North Pond consists of two layers: an upper layer about $400 \mathrm{~m}$ thick with a relatively high permeability and porosity, and a deeper layer (the remainder of the crust) with much lower permeabilities. The decrease in permeability near the bottom of Hole 395A is one of the major discoveries of the cruise.

The sedimentary layer is also an important part of the hydrological system of North Pond. Except for the attempt to measure temperature in the sedimentary layer at Hole 395B, no measurements were made in the sediments on Leg 78B; nor have laboratory measurements of permeability been made on the sediment cores taken on Leg 45. If the carbonate sediments at North Pond have the same permeabilities as sediments with similar compositions and physical properties collected elsewhere, then the sediments may be permeable enough to allow water to flow through them.

\section{DISCUSSION}

The data we have described here and the data given in other reports in this volume provide a one-dimensional profile of thermal and hydrological parameters below 
the seafloor in North Pond. On the reasonable assumption that the low temperatures in the basement below the sediments result from circulation of cold seawater in the upper permeable layer of the crust, in a manner similar to that proposed by Hyndman et al. (1976), we introduce in this section some simple two-dimensional thermal and hydrological models that allow us to estimate (1) the rate of lateral flow of pore water in the basement, (2) the extent to which significant amounts of water may flow through the sedimentary layer, and (3) the bulk permeability of the upper $500 \mathrm{~m}$ of the crust.

\section{Simple Aquifer Model}

A reasonable fit to curve 1 in Figure 3 is obtained by modeling the flow of interstitial water in the ocean crust below the sediment pond as lateral laminar flow in a permeable ocean crust (aquifer). The aquifer is heated from below by constant geothermal flux and held at a fixed temperature at the top. The geometry is shown in Figure 4.

The following simplifying assumptions are made: (1) the flux of pore water is in the horizontal $(x)$ direction only, and the flux is uniform for all $z$ and $x$; (2) sediments in the pond are assumed to be impermeable, and are not included in the thermal model; (3) for $z \geqq l$, the crust is impermeable, and the vertical heat flux $Q$ at $z=$ $l$ is uniform with $x$ and time; (4) the pore water enters the aquifer at a uniform temperature of zero degrees and is everywhere in equilibrium with the crustal rock.

With the above assumptions, heat flows upward in the $z$ direction by conduction only, and both the pore

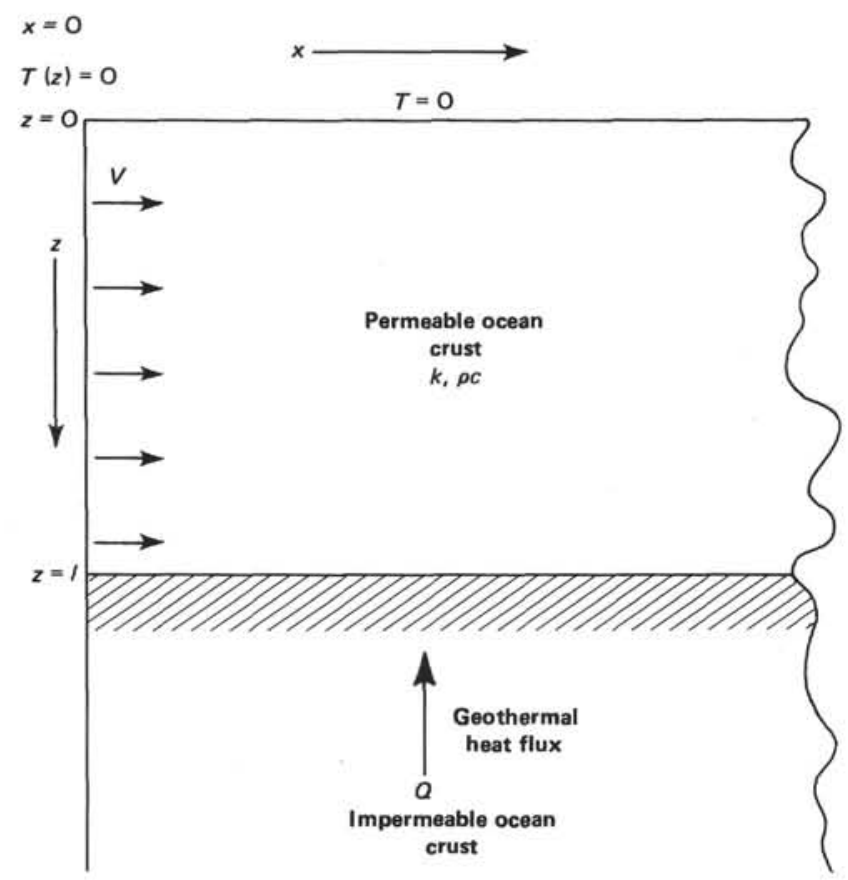

Figure 4. Schematic diagram of the laminar-flow model. A layer of oceanic crust of thickness $l$, permeability $k$, and volumetric heat capacity $\rho c$, overlies an impermeable half-space. Pore water is assumed to flow horizontally through the permeable crust at a Darcian velocity $V$. water and the rock are slowly heated from below as the pore water flows in the $x$ direction. The problem is to determine the temperature $T$ as a function of $z$ and $x$. It can be solved as a one-dimensional, initial-condition problem in conductive heat flow by following a single column of pore water as it moves to larger values of $x$ at a uniform rate $v$ and letting time $t=x / v$.

The equations governing temperature in the column are

$$
\frac{\partial T(z, t)}{\partial t}=\kappa \frac{\partial^{2} T(z, t)}{\partial z^{2}} \quad 0 \leq z \leq l
$$

and

$$
\begin{aligned}
& T(0, t)=0 \quad T(z, 0)=0 \\
& \lambda d T / d z=-Q \text { at } z=l
\end{aligned}
$$

where $\lambda$ and $\kappa$ are the thermal conductivity and thermal diffusivity, respectively, of the basement column.

The solution of (1) that fits the initial and boundary conditions is given by Carslaw and Jaeger (1959). Expressed as error functions it is

$$
\begin{aligned}
T(z, t) & =\frac{2 Q \sqrt{\kappa t}}{\lambda} \sum_{n=0}^{\infty}(-1)^{n}\left[i \text { erfc } U_{1}-i \text { erfc } U_{2}\right] \\
U_{1} & =\frac{(2 n+1) l-z}{\sqrt{\kappa} t} \quad U_{2}=\frac{(2 n+1) l+z}{\sqrt{\kappa} t} \\
i \text { erfc } U & =\int_{U}^{\infty} \operatorname{erfc} \beta d \beta=\frac{1}{\sqrt{\pi}} e^{-U^{2}}-U \text { erfc } U
\end{aligned}
$$

Figure 5A shows the evolution of the temperature profile in the column under the following conditions, which are chosen to approximate the conditions at North Pond: $l=500 \mathrm{~m}, Q=180 \mathrm{~mW} / \mathrm{m}^{2}, \lambda=1.7 \mathrm{~W} /$ $\mathrm{m}^{\circ} \mathrm{C}$, and $\kappa=4.67 \times 10^{-7} \mathrm{~m}^{2} / \mathrm{s}$.

As can be seen in Figure 5A, the 500-m layer requires about 25,000 yrs. to return to steady-state; the observed temperature curve for Hole 395A is in reasonable agreement with a layer that has been warming for about 1000 yrs., and the shape of the observed and theoretical profiles from the laminar-flow model are in reasonable agreement with the sediment temperature measurement in Hole 395B. As expected, a rather steep gradient appropriate to the geothermal heat flow builds up in the lower $100 \mathrm{~m}$ within a few hundred years. The surface heat flow plotted versus time in Figure 5B indicates that for a $500-\mathrm{m}$ layer, significant heat flow is detected only after 1000 yrs., and that the values of heat flow most frequently observed in sediment ponds $\left(35-55 \mathrm{~mW} / \mathrm{m}^{2}\right)$ correspond to warming times of 3000 to $4000 \mathrm{yrs}$.

Hole 395A is about one $\mathrm{km}$ from the rim of North Pond (see Fig. 1). If pore water at bottom temperatures entered there, the laminar aquifer model implies flow rates of $1 \mathrm{~m} / \mathrm{yr}$. and the water would require, on average, about 4000 to 5000 yrs. to pass beneath the pond. These inferred residence times are in accord with the heat flows measured near the center of the pond. 
A

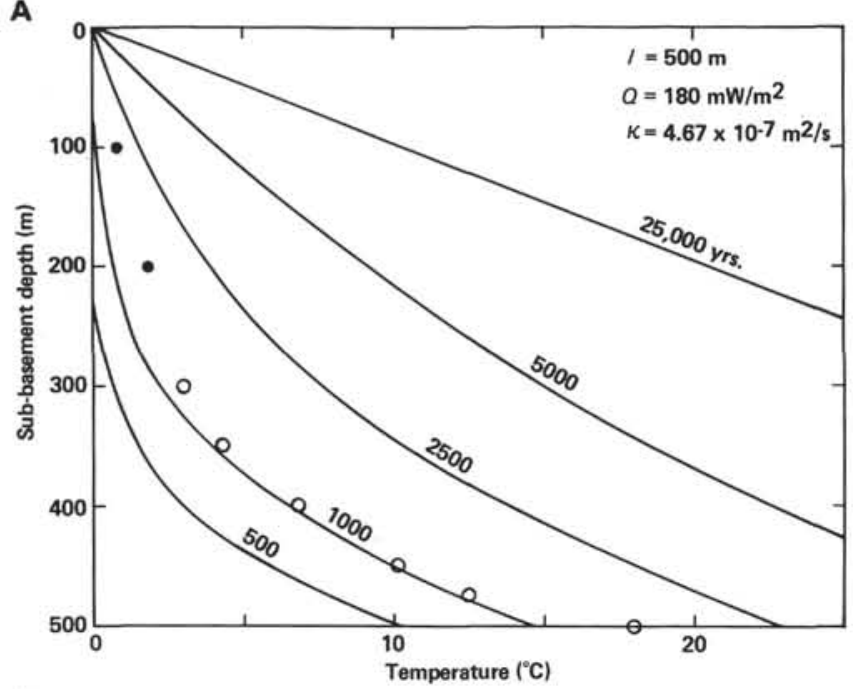

B

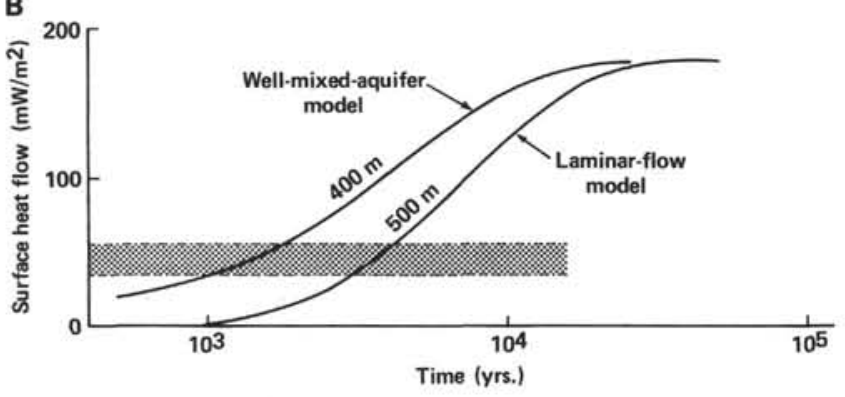

Figure 5. A. Temperature profiles predicted by the laminar-flow model for different durations of warming by geothermal heat. Points from curve 1 in Figure 3 are shown. Circles are observed temperatures, and solid dots are estimated. B. Seafloor heat flow as a function of time for a 500 -m-thick aquifer with laminar flow and a well-mixed 400 -m-thick aquifer (see text). The stippled band is the range of heat-flow values frequently observed in sediment ponds on ridge flanks.

Figure 6 is a cartoon of the temperature field below North Pond for a laminar flow of $1 \mathrm{~m} / \mathrm{yr}$. in the upper $500 \mathrm{~m}$ of crust. More than $85 \%$ of the heat flowing into the bottom of the permeable layer is carried away by the lateral pore-water flow, and is probably lost at the perimeter of the pond. If such flow is taking place, its subsurface pattern could be revealed by carefully mapping the surface heat flow and sediment thickness across the pond.

\section{A Well-Mixed-Aquifer Model}

An alternative to the laminar-flow model is to assume that water in the upper $400 \mathrm{~m}$ of the basement is well mixed by convection, but has a strong lateral component of flux. We will discuss the likelihood of convection later in this section. In this case the temperature of the basement will be essentially uniform to $400 \mathrm{~m}$, and the whole layer will warm slowly by geothermal heat as pore water moves away from its entry area and beneath the pond. Langseth and Herman (1981) described such a thermal model for a well-mixed aquifer flowing at a velocity $v$ in a horizontal layer.
The surface heat flow $(q)$ as a function time $(t)$ since the pore water left the entry point is given by

$$
q=Q\left[1-\exp \left(-\lambda_{s} t / h l \rho c\right)\right]
$$

where $Q$ is the geothermal flux at the base of the layer, $\lambda_{s}$ is the conductivity of the sedimentary layer and $h$ is its thickness, $l$ is the thickness of the well-mixed aquifer layer, and $\rho$ and $c$ are the density and heat capacity, respectively, of the rock-water mixture in the aquifer. Becker et al. (this volume) have estimated the mean temperature in the upper $400 \mathrm{~m}$ to be about $5^{\circ} \mathrm{C}$ above that of bottom water. By equation 2 it would take about 900 yrs. to reach this temperature with $Q=180 \mathrm{~mW} / \mathrm{m}^{2}$.

In general, the well-mixed-aquifer model would require higher flow rates of pore water to produce the observed heat flow over the pond. Figure 5B also shows seafloor heat flow as a function of warming time for the well-mixed-aquifer model. The observed heat flow over isolated sediment ponds would require warming times of 1000 to 2000 yrs. for a well-mixed pore-water layer.

Had the attempt to measure the gradient in the sediment layer near Hole 395A yielded more reliable results, we would have a basis for choosing between the two models. A comparison of inferred pre-drilling temperature profiles and the profile predicted by the laminarflow aquifer model suggests that some vertical mixing occurs, but not enough to bring the whole $400-\mathrm{m}$ layer to a uniform temperature.

\section{Permeability of the Upper Basement Layer}

We were unable to make a successful measurement of permeability in the upper $450 \mathrm{~m}$ of the basement, but we can make a rough estimate from inferred rates of drawdown of bottom water into the hole and an estimate of the initial pore pressure. Becker et al. (this volume) estimated the rate of drawdown to be at least 10 to $20 \mathrm{~m} / \mathrm{hr}$., and Hickman et al. (this volume) made an estimate of the initial pore pressure of about 3 bars subhydrostatic. If we assume that the water drawn down the hole is emptying into a $300-\mathrm{m}$ section of basement, then the infinite-reservoir model of Becker et al. (1983) requires a permeability of at least 0.01 darcies $\left(10^{-14} \mathrm{~m}^{2}\right)$. This value is only a factor of 10 less than the permeability estimated for the upper $90 \mathrm{~m}$ of the ocean crust of the Costa Rica Rift (DSDP Hole 504B), and a factor of 3 higher than the bulk permeability in the deeper sections of Hole 504B (Anderson and Zoback, 1982).

We can also make a rough estimate of bulk permeability from the aquifer model by posing the question: What permeability will allow a $1-\mathrm{m} / \mathrm{yr}$. flow rate with a 3-bar pressure drop from the edge of North Pond to Hole $395 \mathrm{~A} 1 \mathrm{~km}$ to the west?

The permeability of the aquifer cannot be estimated without considering some contribution from seawater flowing through the sedimentary layer. If the sediments are truly impermeable, then the flow can be calculated simply by applying Darcy's law:

$$
v=\frac{k}{\mu} \frac{\Delta P}{\Delta x}
$$



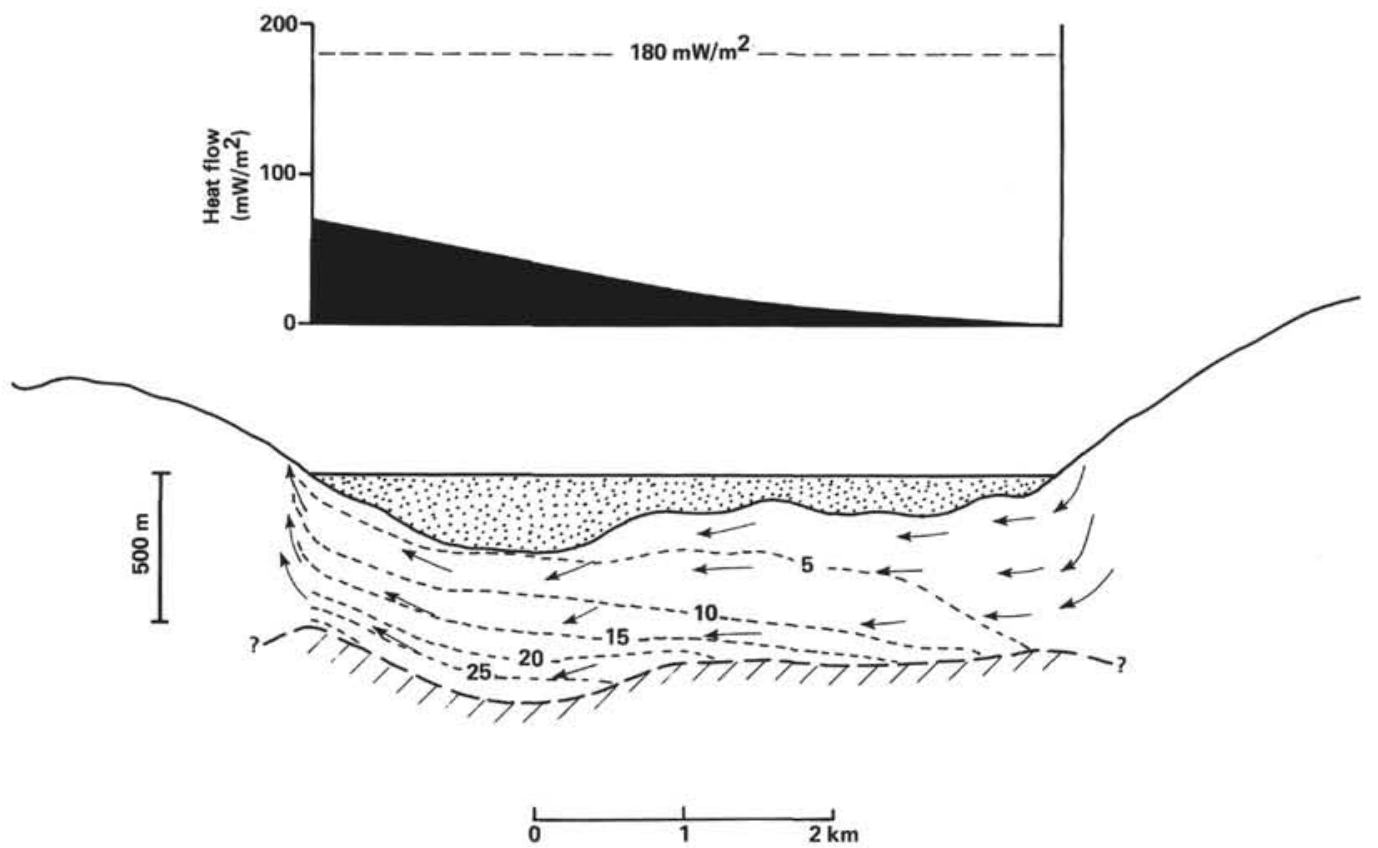

Figure 6. Cartoon of pore-water flow and isotherms $\left({ }^{\circ} \mathrm{C}\right)$ below North Pond, assuming laminar flow at a rate of about $1 \mathrm{~m} / \mathrm{yr}$. The variation in heat flow across the pond is shown along the top of the figure.

where the viscosity $\mu=0.001 \mathrm{~N} \cdot \mathrm{s} / \mathrm{m}^{2}, v=3.2 \times 10^{-8}$ $\mathrm{m} / \mathrm{s}, \Delta x=1000 \mathrm{~m}$, and $\Delta P=3$ bars $=3 \times 10^{5} \mathrm{~N} / \mathrm{m}^{2}$. Substituting these values into equation 3 yields a permeability of 0.1 darcies or $10^{-13} \mathrm{~m}^{2}$, which is one order of magnitude greater than the minimum deduced from the rate of drawdown in the hole during Leg $78 \mathrm{~B}$. Since the initial rate of drawdown was undoubtably higher when the hole was drilled on Leg 45 , the discrepancy may actually be even less.

\section{A Leaky Aquifer}

It is interesting to consider the case of a permeable sedimentary layer. Others have presented evidence based on seafloor sediment temperature profiles that show anomalously low temperature gradients and changes in gradient with depth, which, together with in situ measurements of superhydrostatic and subhydrostatic pore pressure, suggest that pore water may be flowing through the seafloor sediments in some regions (Anderson et al., 1979; Abbott, personal communication, 1983). If significant drawdown of pore water is occurring, it will depress the thermal gradient and thus be an alternative explanation for the low heat flow observed over North Pond.

We present now an idealized model that examines the effects of water flow through the sedimentary layer. It shows that for the geometry of North Pond (i.e., the sediment thickness is $100 \mathrm{~m}$, the permeable basement layer is $500 \mathrm{~m}$ thick, and the influx of water into the basement occurs $1000 \mathrm{~m}$ from the point of interest), water flux through the sediments makes a significant contribution only if the ratio of the permeability of the sediments to that of the basement is greater than 0.01 .

The model of the leaky aquifer is shown in Figure 7A. It consists of a horizontal slab, of thickness $l$ and a permeability $k_{B}$, sandwiched between an impermeable
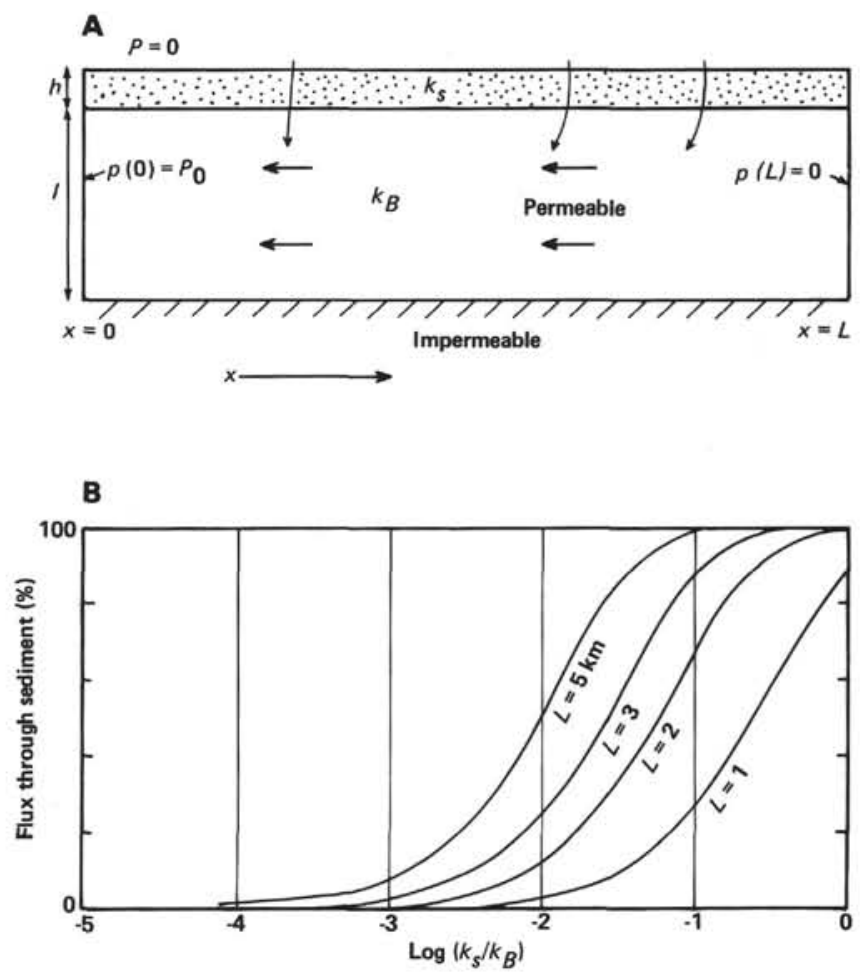

Figure 7. A. Schematic of the leaky-aquifer model, a hydrological model that allows some water flow through the sediment (see text for explanation). B. Plot of the percent of pore water in the aquifer that comes through the sediments, as a function of $k_{s} / k_{B}$ for different aquifer lengths, $L$.

boundary below and, on top, a permeable sedimentary layer of thickness $h$ and permeability $k_{s}$.

The pressure in the aquifer, $p$, is a function of $x$ only: $p(0)=P_{0}$, and at the end of the aquifer $p(L)=0$. Pressure is also assumed to be zero at the top of the sedi- 
mentary layer. For a finite permeability in the sediments, the total flow of pore water along the aquifer, $l \cdot v(x)$, will vary. At any point $x$, the change in $v(x)$ is equal to the gain or loss across the sedimentary layer at that point. Thus:

$$
l \frac{d v}{d x}=\frac{k_{s}}{\mu h} P(x)
$$

but since

$$
v=\frac{k_{B}}{\mu} \frac{d P(x)}{d x},
$$

this equation can be written

$$
\frac{d^{2} P(x)}{d x^{2}}=\frac{k_{s}}{k_{B} l h} P(x)
$$

Solutions to equation 4 are easily derived from the boundary conditions given above:

$$
P(x)=P_{0}\left[e^{-\sqrt{\beta} x}-e^{-\sqrt{\beta} L} \frac{\sin h(\sqrt{\beta} x)}{\sin h(\sqrt{\beta L})}\right]
$$

where $\beta=k_{s} / k_{B} l h$ and

$$
\begin{aligned}
v(x)= & -\frac{k_{B}}{\mu} \frac{d P}{d x}=\frac{P_{0} k_{B} \sqrt{\beta}}{\mu} \\
& {\left[e^{-\sqrt{\beta} x}+e^{-\sqrt{\beta} L} \frac{\cos h(\sqrt{\beta} x)}{\sin h(\sqrt{\beta} L)}\right] }
\end{aligned}
$$

From the last equation we have calculated, as a function of $k_{s} / k_{B}$, the percent of water flow observed at $x=$ 0 that is contributed by flow through the sedimentary layer (see Fig. 7B). For the North Pond geometry used earlier and $k_{s} / k_{B}=0.01$, about $3 \%$ of the pore-water flux in the aquifer comes from the flux of water through the sedimentary layer. For $k_{s} / k_{b}=0.1$, the contribution to the flow is about $25 \%$, which is sufficient to reduce the basement permeability required to produce a flow of $1 \mathrm{~m} / \mathrm{yr}$. If $k_{s} / k_{B}=0.5$, a basement permeability of only $3 \times 10^{-14} \mathrm{~m}^{2}$ is required to allow a lateral flow of $1 \mathrm{~m}$ / yr. at Hole 395A.

Measurements of permeability in marine sediments are still sparse, and there are only a few attempts to categorize the permeability on the basis of sediment type. Bryant et al. (1974) have summarized a large body of data, mainly from the Gulf of Mexico. Most of the results lie between $10^{-18}$ and $10^{-15} \mathrm{~m}^{2}$. Clukey and Silva (1982) report permeabilities of sediments on the east Bermuda Rise and Blake Bahama Outer Ridge that range from $1.1 \times 10^{-18}$ to $7.9 \times 10^{-16} \mathrm{~m}^{2}$. Abbott et al. (1981) have reported a large number of measurements on sediment core samples, as well as in situ measurements made in widely dispersed regions of the oceans. Their results gave values in the range $10^{-16}$ to 8 $\times 10^{-16} \mathrm{~m}^{2}$ for the Guatamala Basin, $10^{-15}<k_{s}<$ $10^{-14} \mathrm{~m}^{2}$ for the Mariana Trough, $6 \times 10^{-16}<k_{s}<$ $1.5 \times 10^{-15} \mathrm{~m}^{2}$ from in situ measurements on the Mis- sissippi Delta, $10^{-16}<k_{s}<8 \times 10^{-16} \mathrm{~m}^{2}$ from measurements in the Wilmington Canyon, and a range of 6 $\times 10^{-16}$ to $1.5 \times 10^{-13} \mathrm{~m}^{2}$ for sediment samples from the central Indian Ocean. Except for the values from the Mariana Trough and a few of the measurements from the Indian Ocean that seem anomalously high, the results fall in the range from $10^{-17}$ to $10^{-15} \mathrm{~m}^{2}$.

The sediments in North Pond are nannofossil foraminiferal ooze. The carbonate content is about 75 to $80 \%$, and the porosity averages about $60 \%$. The cores taken at Site 395 were badly disrupted by the drilling process, but they contained layers of foraminiferal sand and basalt fragments from the surrounding slopes. These types of sediments could have permeabilities near the upper end of the ranges reported above. If the bulk permeability of the sedimentary layer is $10^{-15} \mathrm{~m}^{2}$, then the ratio $k_{s} / k_{B}$ would be relatively large, and significant drawdown of water through the sedimentary layer (about 3 $\times 10^{-9} \mathrm{~m} / \mathrm{s}$ ) is possible. At the temperatures observed in the sedimentary layer $\left(1-3^{\circ} \mathrm{C}\right.$ above the bottom-water temperature), a flux of $3 \times 10^{-9} \mathrm{~m} / \mathrm{s}$ could depress the heat flow by a few tens of $\mathrm{mW} / \mathrm{m}^{2}$. If the permeability of the sediments in North Pond is greater than $10^{-15}$ $\mathrm{m}^{2}$, the drawdown of seawater will play a major role in shaping the observed temperature profile. However, some evidence against drawdown through the sediments (upper limit of $0.2 \times 10^{-9} \mathrm{~m} / \mathrm{s}$ ) is provided by pore fluid chemistry (McDuff, this volume).

\section{Convection in Upper Part of Basement}

If a permeability of $10^{-13} \mathrm{~m}^{2}$ is an upper limit for values in the top $400 \mathrm{~m}$ of the oceanic basement, then convection on a scale of 400 to $500 \mathrm{~m}$ is barely possible. For a porous medium heated from below, the governing Rayleigh number is

$$
R_{a} \equiv \frac{\alpha g \rho_{w} k l^{2} Q}{\mu \kappa \lambda}
$$

where

$$
\begin{aligned}
\alpha= & \text { thermal expansion coefficient of water } \\
& \left(10^{-3} /{ }^{\circ} \mathrm{C}\right) \\
g= & \text { acceleration due to gravity }\left(10 \mathrm{~m} / \mathrm{s}^{2}\right), \\
k= & \text { permeability }\left(10^{-13} \mathrm{~m}^{2}\right), \\
l= & \text { layer thickness }(400 \mathrm{~m}), \\
Q= & \text { heat flux from below }\left(0.180 \mathrm{~W} / \mathrm{m}^{2}\right), \\
\mu= & \text { viscosity }\left(10^{-3} \mathrm{~N} \cdot \mathrm{s} / \mathrm{m}^{2}\right) \\
\lambda= & \text { thermal conductivity }\left(1.7 \mathrm{~W} / \mathrm{m}^{\circ} \mathrm{C}\right), \\
\rho_{w}= & \text { density of water }\left(10^{3} \mathrm{~kg} / \mathrm{m}^{3}\right) \\
\kappa= & \text { thermal diffusivity of the layer } \\
& \left(4.67 \times 10^{-7} \mathrm{~m}^{2} / \mathrm{s}\right)
\end{aligned}
$$

With these values the Rayleigh number is 36 . The critical Rayleigh number for convection in a porous medium is about 40 (see, e.g., Ribando et al., 1976). Thus, the conditions for convection are nearly met. It seems likely that the permeability and thickness of the permeable upper layer vary significantly in the lateral dimension, so that in reality, convection may occur in some localized areas and be inhibited in others. This may ex- 
plain the earlier conclusion, based on the thermal analysis, that pore water flowing laterally through the basement appears to be partially mixed.

\section{CONCLUDING REMARKS}

The comprehensive suite of observations in Hole $395 \mathrm{~A}$ indicates that, despite the large areal extent of the sedimentary blanket of North Pond (about $40 \mathrm{~km}^{2}$ ), the thermal regime of the ocean crust beneath the Pond is profoundly disturbed by seawater circulation. Our analysis shows that the horizontal flow of porewater through permeable layers of basement must be on the order of a meter per year to explain the discrepancy observed between theoretical and observed heat-flow values. We also show that drawdown of water through the sedimentary layer is possible, though it has not been demonstrated to occur. There are thousands of sediment ponds similar to North Pond dotting the flanks of mid-oceanic ridges. Heat-flow measurements in many of these ponds yield remarkably uniform values that also represent only a small fraction of the theoretically expected heat flow. Thus, many-perhaps most-of these ponds have similar thermal regimes at depth. There seems to be little hope that the heat flow through the surfaces of such ponds can be used to determine the heat flow from deep in the lithosphere, unless there is an independent and easy way to determine the rate and geometry of seawater circulation beneath them.

Current interest centers on how the development of inter-montane sediment ponds affects the thermal evolution and alteration of the oceanic basement beneath them. Marine geological evidence indicates that these ponds grow rapidly. The oldest sediment cored at Site 395 is about $6 \mathrm{Ma}$ old, and the site is near the edge of the pond. The pond continues to grow as long as the surrounding slopes, which are the sources of the sediment that is filling the pond, are above the carbonate compensation depth. The growth of the low-permeability blanket will increasingly restrict and inhibit circulation in the crust below the pond compared with the circulation in adjacent regions of exposed basement. As the flow slows, isotherms will move upward beneath the pond. This promotes alteration of the basement rocks, which in turn accelerates the sealing of fractures and voids, thus slowing circulation even further and allowing geothermal heat to warm higher levels in the basement.

Our earlier analysis also showed that in these intermontane ponds the permeability ratio of sediments to basement rock may be high enough to allow significant flux of water down through the sediments. This pore water could carry significant amounts of calcium carbonate downward into the upper part of the basement and perhaps promote calcite precipitation in fractures and voids. This cementation will further channelize the flow of water through the basement. Thus, the isolated ponds of sediment on the ridge flanks may produce highly altered zones within the basement that could be visible in ophiolite complexes.

The pioneering downhole measurements in Hole $395 \mathrm{~A}$ raised several questions that can be answered by further geophysical surveying and drilling in North Pond or other similar ponds. A detailed heat-flow and high-resolution seismic survey across North Pond could map the flow pattern of pore water beneath the sedimentary layer. In situ measurements of pore pressure in the sediment could resolve the question of whether there is advection of water through the sedimentary layer. Hydraulic piston coring of the sedimentary deposits in North Pond could provide new data on how such ponds form and could provide excellent samples for the measurement of hydraulic and other physical properties. Understanding one isolated sediment pond on a ridge flank in detail will provide insight into the hydrogeological nature and evolution of all such ponds.

\section{ACKNOWLEDGMENTS}

The large number of measurements and experiments that were successfully carried out on Leg 78B were possible in large degree because of the skill and dedication of the drillers and crew of the Glomar Challenger. P. Thompson and G. Gustavson provided critical assistance that led to successful operation of the packer and downhole temperature-probe equipment. NSF grant 81-09925 supported the research reported here. This chapter is Earth Physics Branch Contribution 1091 .

\section{REFERENCES}

Abbott, D., Menke, W., Hobart, M., and Anderson, R. N., 1981. Evidence for excess pore pressure in southwest Indian Ocean sediments. J. Geophys. Res., 86:816-828.

Anderson, R. N., Hobart, M. A., and Langseth, M. G., 1979. Geothermal convection through oceanic crust and sediments in the Indian Ocean. Science, 204:828-832.

Anderson, R. N., and Zoback, M. D., 1982. Permeability, underpressure, and convection in oceanic crust near the Costa Rica Rift, Eastern Equatorial Pacific. J. Geophys. Res., 87:2860-2868.

Becker, K., Langseth, M. G., and Von Herzen, R. P., 1983. Deep crustal geothermal measurements, Hole 504B, Deep Sea Drilling Project Legs 69 and 70. In Cann, J. R., Langseth, M. G., Honnorez, J., Von Herzen, R. P., White, S. M., et al., Init. Repts. $D S D P, 69$ : Washington (U.S. Govt. Printing Office), 213-235.

Bryant, W. R., Deflache, A. P., and Trabant, P. K., 1974. Consolidation of marine clays and sediments. In Inderbitzen, A. L. (Ed.), Deep Sea Sediments (Vol. 2): New York and London (Plenum Press).

Carslaw, H. S., and Jaeger, J., 1959. Conduction of Heat in Solids: Oxford, England (Clarendon Press).

Clukey, E. C., and Silva, A. J., 1982. Permeability of deep-sea clays: northwestern Atlantic. Mar. Geotech., 5:1-26.

Davis, E. E., and Lister, C. R. B., 1977. Heat flow measured over the Juan de Fuca Ridge: Evidence for widespread hydrothermal circulation in a highly heated transportive crust. J. Geophys. Res., 82: 4845-4860.

Erickson, A. J., Von Herzen, R. P., Sclater, J. G., Girdler, R. W., Marshall, B. V., and Hyndman, R. D., 1975. Geothermal measurements in deep-sea drill holes. J. Geophys. Res., 80:2515-2528.

Erickson, A. J., and Hyndman, R. D., 1979. Downhole temperature measurements and thermal conductivities of samples, Site 396 , Deep Sea Drilling Project Leg 46. In Tucholke, B. E., Vogt, P. R., et al., Init. Repts. DSDP, 46: Washington (U.S. Govt. Printing Office), 389-400.

Hussong, D. M., Fryer, P. B., Tuthill, J. D., and Wipperman, L. K., 1979. The geological and geophysical setting near Site 395, North Atlantic. In Melson, W. G., Rabinowitz, P. D., et al., Init. Repts. DSDP, 45: Washington (U.S. Govt. Printing Office), 23-38.

Hyndman, R. D., Von Herzen, R. P., Erickson, A. J., and Jolivet, J., 1976. Heat flow measurements in deep crustal holes on the MidAtlantic Ridge. J. Geophys. Res., 81:4053-4060.

Kasahara, J. Hussong, D. M., and Sutton, G. H., 1980. A seismic study using ocean-bottom seismometers near the Mid-Atlantic Ridge at $23^{\circ}$ N. Mar. Geol., 35:199-218. 
Kirkpatrick, R. J., 1979. The physical state of the oceanic crust: Results of downhole geophysical logging in the Mid-Atlantic Ridge at $23^{\circ}$ N. J. Geophys. Res., 84:178-188.

Langseth, M. G., and Herman, B. M., 1981. Heat transfer in the oceanic crust of the Brazil Basin. J. Geophys. Res., 86:10805-10819.

Lawrence, J. R., and Drever, J. I., 1981. Evidence for cold water circulation at DSDP Site 395: Isotopes and chemistry of alteration products. J. Geophys. Res., 86:5125-5133.

Lister, C. R. B., 1972. On the thermal balance of a mid-ocean ridge. Geophys. J. R. Astron. Soc., 26:515-535.

Melson, W. G., Rabinowitz, P. D., et al., 1979. Init. Repts. DSDP, 45: Washington (U.S. Govt. Printing Office).

Ribando, R. J., Torrence, K. E., and Turcotte, D. L., 1976. Numerical models for hydrothermal circulation in the oceanic crust. J. Geophys. Res., 81:3007-3012.
Talwani, M., Windisch, C. C., and Langseth, M. G., 1971. Reykjanes Ridgecrest: A detailed geophysical study. J. Geophys. Res., 76: 473-517.

van Andel, T. H., and Komar, P. D., 1969. Ponded sediments of the Mid-Atlantic Ridge between $22^{\circ}$ and $23^{\circ}$ north latitude. Bull. Geol. Soc. Am., 80:1163-1190.

Whitmarsh, R. B., 1978. Seismic refraction studies of the upper igneous crust in the North Atlantic and porosity estimates for Layer 2. Earth Planet. Sci. Lett., 37:451-464.

Yokota, T., Kinoshita, H., and Uyeda, S., 1980. New DSDP (Deep Sea Drilling Project) downhole temperature probe utilizing IC RAM (memory) elements. Bull. Earthquake Res. Inst., 55:75-88.

Date of Initial Receipt: September 23, 1983

Date of Acceptance: September 26, 1983 